\title{
ANALISIS NILAI-NILAI PENDIDIKAN KARAKTER DALAM PEMBUATAN DOMPET PUNCH ZAMAN NOW
}

\author{
Deddy Febrianshari' ${ }^{1)}$, Vivian Cahaya Kusuma ${ }^{2)}$, Nida Dwi Jayanti' \\ Dyah Worowirastri Ekowati ${ }^{4)}$, Mukhamad Yunus Prasetya ${ }^{5}$, Widiyanti $^{6}$, Beti \\ Istanti Suwandayani ${ }^{7)}$ \\ ${ }^{1,2,3)}$ Universitas Muhammadiyah Malang \\ e-mail: deddywara@gmail.com
}

\begin{abstract}
This paper consists of describing about education character values in the making punch zaman now. This aim is to describe about informasion about its values. The results showed that the values of character education contained in the manufacture of punch of the present era are 6, the value of discipline character, the value of hard work character, the value of the creative character, the value of the character appreciate the achievement, the value of environmental care characters, and the value of the character of responsibility. So, in the making of punch era now there are values of characters that can be associated with teaching character education schools in Indonesia.
\end{abstract}

Keywords: value, character, education

\begin{abstract}
Abstrak: Pemikiran ini mengandung pemapaparan tentang nilai-nilai pendidikan karakter dalam pembuatan punch zaman now. Tujuan pemikiran ini untuk mendeskripsikan data tentang nilai nilai yang terkandung dalam pembuatan dompet punch zaman now. Hasil pemikira ini menunjukkan bahwa nilai-nilai pendidikan karakter yang terkandung dalam pembuatan punch zaman now ada 6 yaitu, nilai karakter disiplin, nilai karakter kerja keras, nilai karakter kreatif, nilai karakter menghargai prestasi, nilai karakter peduli lingkungan, dan nilai karakter tanggung jawab. Jadi dalam pembuatan punch zaman now terdapat nilai-nilai karakter yang dapat dikaitkan dengan pengajaran pendidikan karakter sekolah di Indonesia.
\end{abstract}

Kata kunci: nilai, karakter, pendidikan

\section{PENDAHULUAN}

Bidang pendidikan memiliki tugas yang tidak ringan dalam menghadapi era globalisasi saat ini. Terlebih semakin pesatnya pembangunan nasional yang menuntut adanya generasi yang lebih maju disamping mempersiapkan peserta didik untuk meningkatkan ilmu pengetahuan dan teknologi (IPTEK). Undang-undang Republik Indonesia nomor 20 tahun 2003 tentang Sistem Pendidikan Nasional (UU Sisdiknas) merumuskan fungsi dan tujuan pendidikan nasional yang harus digunakan dalam mengembangkan upaya pendidikan di Indonesia.

Pendidikan nasional berfungsi mengembangkan dan membentuk watak serta peradaban bangsa yang bermartabat dalam rangka mencerdaskan kehidupan bangsa, bertujuan untuk berkembangnya potensi peserta didik agar menjadi manusia yang beriman dan bertakwa kepada Tuhan Yang Maha Esa, berakhlak mulia, sehat, berilmu, cakap kreatif, mandiri dan menjadi warga negara yang demokratis serta bertanggung jawab.

Tujuan pendidikan nasional merupakan rumusan mengenai kualitas manusia Indonesia yang harus dikembangkan oleh setiap lembaga. Oleh karena itu, rumusan pendidikan nasional menjadi dasar dalam mengembangkan pendidikan. Penyelenggaraan pendidikan harus dilaksanakan secara sistematis untuk mencapai tujuan pendidikan tersebut. 
Sistem pendidikan di Indonesia saat harus selalu dikembangkan sesuai dengan kebutuhan dan perkembangan yang terjadi baik di tingkat lokal, nasional maupun global.

Pendidikan karakter telah menjadi kebijakan pendidikan nasional yang diimplementasikan ke dalam kurikulum nasional. Pendidikan karakter ini muncul berdasarkan belum berhasilnya sistem pendidikan menciptakan lulusan yang memiliki keseimbangan kompetisi antara kemampuan (kognitif), ketrampilan (psikomotorik) dan sikap (afektif) yang sebenarnya telah menjadi filosofi dalam pendidikan Indonesia.

Indonesia merupakan negara agraris yang sayang indah keadaan geografisnya yang beranekaragam, bahasa, serta suku dan budayanya. Namun berbanding terbalik dengan keadaan sosial yang ada di Indonesia. Pendidikan untuk pembentukan moral (moral education) atau pembentukan karakter (character education) dalam konteks sekarang ini sangat relevan untuk mengatasi berbagai hal permasalahan tentang degradasi moral pada anak bangsa. Krisis moral yang yang sedang melanda anak bangsa saat ini misalnya pergaulan bebas, maraknya angka kekerasan dan pelecehan seksual terhadap anak dan remaja, kejaharan terhadap teman, pencurian, dan penyalahgunaan obat-obatan merupakan masalah sosial yang hingga saat ini masih belum dapat diatasi secara tuntas. Hal ini menandakan masyarakat Indonesia saat ini sedang mengalami gejala patologi sosial yang sangat mengkhawatirkan dan harus segera ditangani.

Data menunjukkan bahwa $68 \%$ siswa sekolah dasar (SD) sudah aktif mengakses konten porno (Zubaidah dalam sindonews.com, 2013). Sedangkan pada lima tahun lalu Indonesia telah masuk dalam 10 besar negara yang mengakses situs pornografi di dunia maya. Data Kementrian Komunikasi dan Informatika juga menunjukkan bahwa terjadi peningkatan setiap tahun dalam permasalahan tersebut. Perilaku tersebut seperti sudah menjadi indikator dekandesi moral serta etika pada peserta didik. Menurut Lickona $(2013,20)$ terdapat 10 indikasi gejala penurunan moral yang perlu mendapat perhatian agar berubah ke arah yang lebih baik, 1) kekerasan, 2) pencurian, 3) tindakan curang, 4) pengabaian terhadap aturan, 5) tawuran, 6) penggunaan bahasa yang tidak baik, 7) ketidaktoleran, 8) kematangan seksual yang terlalu dini, 9) sikap perusakan diri, 10) penyalahgunaan narkoba.

Dalam menyelesaikan permasalahan tersebut pendidikan karakater tentunya menjadi salah satu upaya yang dapat digunakan dan dilasanakan oleh sekolag dan pendidik. Menurut Lickona dalam Samana (2013, 44) pendidikan karakter adalah bentuk upaya yang dirancang secara sengaja untuk memperbaiki karakter peserta didik. Menurut Kemendiknas (2010, 7) salah satu tujuan dari pendidikan karakter adalah untuk mengembangkan kebiasaan dan perilaku peserta didik yan terpuji dan sejalan dengan nilai-nilai universal dan tradisi budaya bangsa yang religius.

Selain untuk menanggulangi permasalahan yang terjadi, pendidikan karakter merupakan tugas dan tanggung jawab sekolah serta pendidik. Dengan demikian pendidikat dapat menciptakan generasi muda yang berkarakter baik, dalam membangun generasi emas 2045 . Dalam pendidikan karakter terdapat nilai nilai yang dapat diimplementasikan untuk menuju ke arah pendidikan yang baik. 


\section{Pendidikan Karakter}

Pendidikan karakter telah menjadi perhatian berbagai negara dalam rangka mempersiapkan generasi yang berkualitas, bukan hanya untuk kepentingan individu tetapi untuk warga masyarakat pada umumnya. Pengertian pendidikan karakter adalah the deliberate us of all dimensions of school life to foster optimal character develompment. Yang artinya bahwa pendidikan karakter merupakan usaha secara sengaja dari seluruh dimensi kehidupan sosial untuk membantu pembentukan karakter secara optimal.

Pendidikan karakter mulai dikenalkan sejak tahun 1900-an yang diusung oleh Thomas Lockona dalam bukunya yang berjudul the return of character education dan teach respect and responsibility. Melalui buku buku tersebut dunia barat mulai sadar akan pentingnya pendidikan karakter. Unsur dalam pendidikan karakter antara lain: mengetahui kebaikan, mencintai kebaikan dan melakukan kebaikan.

Pendidikan karakter bukan hanya sebatas menjelaskan kepada peserta didik akan kebenaran dan kesalahan saja, tetapi lebih dari itu pendidikan karakter harus mampu menanamkan kebiasaan atau habituatuation tentang yang baik seihngga peserta didik mampu merasakan dan dapat mengimplementasikan dalam kehidupan sehari-hari. Jadi pendidikan karakter akan membawa misi yang sama dengan pendidikan akhlak atau pendidikan moral peserta didik.

\section{Pendidikan Kewirausahaan}

Standar nasional pendidikan yang menjadi acuan pengembangan kurikulum, pendidikan kewirausahaan juga termasuk dalam materi yang harus diajarkan dan dikuasai serta direalisasikan oleh peserta didik dalam kehidupan sehari-hari. Pendidikan kewirausahaan di sekolah selama ini baru menyentih pada tingkatan pengenalan nilai-nilai dan belum pada tingkatan internasilisasi dan tindakan nyata dalam kehidupan sehari-hari. Di samping itu, berlakunya sistem desentralisasi berpengaruh pada berbagai tatanan kehidupan, termasuk pada manajemen pendidikan yaitu manajemen yang memberi kebebasan kepada pengelolaan pendidikan.

Kewirausahan adalah suatu sikap, jiwa dan kemampuan untuk menciptakan sesuatu yang baru yang sangat bernilai dan berguna bagi dirinya dan orang lain. Kewirausahaan merupakan sikap mental dan jiwa yang selalu aktif atau kreatif berdaya, bercipta, berkarya dan bersahaja dan berusaha dalam rangka meningkatkan pendapatan dalam kegiatan usahanya. Seseorang yang memiliki karakter selalu tidak puas dengan apa yang telah dicapainya. Wirausaha adalah orang yang terampil memanfaatkan peluang dalam mengembangkan usahanya dengan tujuan untuk meningkatkan kehidupannya (Kemdiknas, 2010).

Norman M. Scarborough dan Thomas W. Zimmerer (1993:5), dalam Kemendiknas (2010), "An entrepreneur is one who creates a newbusiness in the face if risk and uncertainty for the purpose of achieving profit andgrowth by identifying opportunities and asembling the necessary resources to capitalzeon those opportunities". Wirausahawan adalah orang-orang yang memiliki kemampuan melihat dan menilai kesempatan-kesempatan bisnis; mengumpulkan sumber daya-sumber daya yang dibutuhkan untuk mengambil tindakan yang tepat, mengambil keuntungan serta memiliki sifat, watak dan kemauan untuk mewujudkan gagasan inovatif kedalam dunia nyata secara kreatif dalam rangka meraih sukses/meningkatkan pendapatan. 
Intinya, seorang wirausaha adalah orangorang yang memiliki karakter wirausaha dan mengaplikasikan hakikat kewirausahaan dalam hidupnya. Dengan kata lain, wirausaha adalah orang-orang yang memiliki jiwa kreativitas dan inovatif yang tinggi dalam hidupnya.

Pendidikan kewirausahaan di

Indonesia masih kurang memperoleh perhatian yang cukup memadai, baik oleh dunia pendidikan maupun masyarakat.Banyak pendidik yang kurang memperhatikan penumbuhan karakter dan perilaku wirausaha peserta didik, baik di sekolah-sekolah kejuruan, maupun di pendidikan profesional.Orientasi mereka, pada umumnya hanya pada menyiapkan tenaga kerja.Untuk itu, perlu dicari penyelesaiannya, bagaimana pendidikan dapat berperan untuk mengubah manusia menjadi manusia yang memiliki karakter dan atau perilaku wirausaha. Untuk mencapai hal tersebut bekal apa yang perlu diberikan kepada peserta didik agar memiliki karakter dan atau perilaku wirausaha yang tangguh, sehingga nantinya akan dapat menjadi manusia yang jika bekerja di kantor akan akan menjadi tenaga kerja yang mandiri kerja dan jika tidak bekerja di kantor akan menjadi manusia yang mampu menciptakan lapangan perkerjaan minimal bagi dirinya sendiri.

\section{Nilai-Nilai yang Terkandung dalam Kewirausahaan}

Nilai merupakan realita abstrak.

Nilai kita rasakan dalam diri kita masing-masing sebagai daya pendorong atau prinsip-prinsip yang menjadi pedoman daam hidup. Oleh sebab itu, nilai menduduki tempat penting dan strategis dalam kehidupan seseorang, sampai pada suatu tingkat di mana orang lebih siap untuk mengirbankan hidup mereka daripada mengorbankan nilai (Fitri, 2012:89)
Nilai adalah hal yang terkandung dalam diri (hati nurani) manusia yang lebih memberi dasar pada prinsip akhlak yang merupakan dasar dari keindahan dan efisiensi atau keutuhan kata hati (Sumantri dalam Gunawan, 2012 : 31). Selanjutnya (Richard Eyre dan Linda dalam Gunawan, 2012:31) menyebutkan bahwa nilai yang benar dan diterima secara universal adalah nilai yang menghasilkan suatu perilaku dan perilaku itu berdampak positif, baik bagi yang menjalankan maupun bagi orang lain.

Berdasarkan beberapa definisi di atas peneliti dapat menyimpulkan bahwa nilai adalah hal yang terkandung dalam diri manusia yang kemudian menghasilkan perilaku positif dimana berperan sebagai daya pendorong yang menjadi pedoman dalam hidup.

Pengertian karakter dapat dilihat dari dua sisi, yaitu sisi kebahasaan dan sisi istilah. Menurut bahasa (etimologis) istilah karakter berasal dari bahasa Latin kharakter, kharassaein, dan kharax, dalam bahasa Yunani character dari kata charassein, yang berarti membuat tajam dan membuat dalam (Gunawan, 2012: 1). Dalam kamus psikologi, arti karakter adalah kepribadian ditinjau dari titik tolak etis atau moral, misalnya kejujuran seseorang. Ada istilah yang pengertiannya hampir sama dengan karakter, yaitu personaliti, yang sama konsisten diperagakan oleh seseorang, termasuk pola-pola prilaku, sifat-sifat fisik, dan ciri-ciri kepribadian (Fitri, 2012: 20).

Sementara menurut istilah (terminologis), karakter diartikan sebagai sifat manusia pada umumnya yang bergantung pada faktor kehidupannya sendiri. Karakter adalah sifat kejiwaan, akhlak, atau budi pekerti yang menjadi cirri khas seseorang atau sekelompok orang (Fitri, 2012: 20). Karakter merupakan nilai-nilai perilaku 
manusia yang berhubungan dengan Tuhan Yang Maha Esa, diri sendiri, sesamam manusia, lingkungan, dan kebahasaan, yang terwujud dalam pikiran, sikap, perasaan, perkataan, dan perbuatan berdasarkan norma norma agama, hukum, tata karma, budaya, dan adat istiadat. Karakter juga diartikan sama dengan akhlak bangsa dan budi pekerti. Sebaliknya, bangsa yang tidak berkarakter adalah bangsa yang tidak berakhlak atau tidak memiliki standar norma dan perilaku yang baik.

Menurut Hermawan Kertajaya (dalam Gunawan, 2012:2), mendefinisikan karakter adalah ciri khas yang dimiliki oleh suatu benda atau individu (manusia). Ciri khas tersebut adalah asli dan mengakar pada kepribadian benda atau individu tersebut dan merupakan mesin pendorong bagaimana seseorang bertindak, bersikp, berujar, serta merespon sesuatu.

sosiasi

Supervisi dan Pengembangan Kurikulum di Amerika Serikat, mendefinisikan pendidikan karakter adalah sebuah proses pengajaran kepada anak-anak tentang nilai-nilai kemanusiaan dasar, termasuk di dalamnya kejujuran, keramahtamahan, kemurahan hati, keberanian, kebebasan, persamaan, dan rasa hormat. Tujuannya adalah untuk menumbuhkan diri siswa sebagai warga Negara yang dapat bertanggung jawab secara moral dan memiliki disiplin diri (Koesoma A., 2012: 58).

Pendidikan karakter adalah usaha aktif untuk membentuk kebiasaan (habit) sehingga sifat anak akan terukir sejak dini, agar dapat mengambil keputusan dengan baik dan bijak serta mempraktikkannya dalam kehidupan sehari-hari (Fitri, 2012: 21).

$$
\text { Menurut Ramli (dalam }
$$

Gunawan, 2012: 24) pendidikan karakter memiliki esensi dan makna yang sama dengan pendidikan moral dan pendidikan akhlak. Tujuannya adalah membentuk pribadi anak, supaya menjadi manusia yang baik, warga masyarakat, dan warga negara yang baik. Adapun kriteria manusia yang baik, warga masyarakat, dan warga negara yang baik bagi suatu masyarakat atau bangsa, secara umum adalah nilai-nilai sosial tertentu, yang banyak dipengaruhi oleh budaya masyarakat dan bangsanya. Oleh karena itu, hakikat dari pendidikan karakter dalam konteks pendidikan di Indonesia adalah pendidikan nilai, yakni pendidikan nilai-nilai luhur yang bersumber dari budaya bangsa Indonesia sendiri, dalam rangka membina kepribadian generasi muda.

Menurut Sahlan dan Prasetyo ( 2012: 3940) Kemendikbud merilis beberapa nilai-nilai pendidikan karakter terbagi menjadi 18 nilai sebagai berikut.

1. Religius

Religius merupakan sikap dan perilaku yang patuh dalam melaksanakan ajaran agama yang dianutnya. Tujuan adanya penanaman nilai-nilai religius adalah untuk mengembangkan kepribadian, karakter yang tercermin dalam kesalehan pribadi maupun sosial diantara seluruh warga sekolah/madrasah (Sahlan dan Prasetyo, 2012: 38).

2. Jujur

Jujur merupakan perilaku yang didasarkan pada upaya menjadikan dirinya sebagai orang yang selalu dapat dipercaya dalam perkataan, tindakan, dan pekerjaan. Kejujuran dan kebajikan selalu terkait dengan kesan terpercaya. Terpercaya selalu terkait dengan kesan tidak berdusta, menipu, atau memperdaya. Hal ini terwujud dalam tindak dan perkataan. Semua pihak percaya bahwa hakim dapat mempertahankan integritasnya dengan membuat keputusan yang fair. 
Ia percaya karena keputusannya mencerminkan kejujuran (Fitri, 2012: 112).

3. Toleransi

Toleransi merupakan sikap dan tindakan yang menghargai perbedaan agama, suku, etnis, pendapat, sikap, dan tindakan orang lain yang berbeda dari dirinya.

4. Disiplin

Disiplin merupakan tindakan yang menunjukkan perilaku tertib dan patuh pada berbagai ketentuan dan peraturan.

5. Kerja keras

Kerja keras merupakan perilaku yang menunjukkan upaya sungguhsungguh dalam mengatasi berbagai hambatan belajar dan tugas, serta menyelesaikan tugas dengan sebaikbaiknya.

6. Kreatif

Kreatif merupakan berpikir dan melakukan sesuatu untuk menghasilkan cara atau hasil baru dari sesuatu yang telah dimiliki.

7. Mandiri

Mandiri merupakan sikap dan perilaku yang tidak mudah tergantung pada orang lain dalam menyelesaikan tugas-tugas.

8. Demokratis

Demokratis merupakan cara berpikir, bersikap, dan bertindak yang menilai sama hak dan kewajiban dirinya dan orang lain.

9. Rasa ingin tahu

Rasa ingin tahu merupakan sikap dan tindakan yang selalu berupaya untuk mengetahui lebih mendalam dan meluas dari sesuatu yang dipelajarinya, dilihat, dan didengar.

10. Semangat Kebangsaan

Semangat kebangsaan merupakan cara berpikir, bertindak, dan berwawasan yang menempatkan kepentingan bangsa dan Negara di atas diri dan kelompoknya.
11. Cinta tanah air

Cinta tanah air merupakan cara berpikir, bersikap, dan berbuat yang menunjukkan kesetiaan, kepedulian, dan penghargaan yang tinggi terhadap bangsa, lingkungan fisik, sosial, budaya, ekonomi dan politik bangsa.

12. Menghargai Prestasi

Menghargai prestasi merupakan sikap dan tindakan yang mendorong dirinya untuk menghasilkan sesuatu yang berguna bagi masyarakat, dan mengakui, serta menghormati keberhasilan orang lain.

13. Bersahabat/Komunikatif

Bersahabat/komunikatif merupakan tindakan yang memperlihatkan rasa senang berbicara, bergaul, dan bekerja sama dengan orang lain.

14. Cinta Damai

Cinta damai merupakan sikap, perkataan, dan tindakan yang menyebabkan orang lain merasa senang dan aman atas kehadiran dirinya.

15. Gemar Membaca

Gemar membaca merupakan kebiasaan menyediakan waktu untuk membaca berbagai bacaan yang memberikan kebajikan bagi dirinya.

16. Peduli Lingkungan

Peduli lingkungan merupakan sikap dan tindakan yang selalu berupaya mencegah kerusakan pada lingkungan alam di sekitarnya, dan mengembangkan upaya-upaya untuk memperbaiki kerusakan alam yang sudah terjadi

17. Peduli Sosial

Peduli sosial merupakan sikap dan tindakan yang selalu ingin memberi bantuan pada orang lain dan masyarakat yang membutuhkan.

18. Tanggung Jawab

Tanggung jawab merupakan sikap dan perilaku seseorang untuk 
melaksanakan tugas dan kewajibannya, yang seharusnya dia lakukan, terhadap diri sendiri, masyarakat, lingkungan (alam, sosial, dan budaya), Negara dan Tuhan Yang Maha Esa.

Nilai yang terkandung dalam pembuatan dompet punch zaman now ini antara lain, nilai karakter disiplin, nilai karakter kerja keras, nilai karakter kreatif, nilai karakter peduli lingkungan, dan nilai karakter tanggung jawab. Dalam proses pembuatan dimulai dengan mengumpulkan banner bekas yang sudah menjadi limbah kegiatan di wilayah kampus UMM. Limbah banner tersebut tentunya sulit terurai jika dibiarkan. Maka dari ibu untuk menciptakan rasa cinta atau peduli lingkungan dilakukanlah pemrosesan awal limbah banner untuk dimanfaat menjadi barang yang bernilai jual tinggi.

Engkoswara (1999), menyatakan bahwa tantangan yang terjadi pada era Global adalah semakin menipisnya kualitas kemandirian manusia Indonesia.Krisis yang melanda Indonesia yang multidimensi mengakibatkan budaya bangsa semakin memudar, yaitu terjadinya degradasi moral spiritual, semangat berusaha dan bekerja yang semakin melemah, kreativitas yang semakin mengerdil dan menjurus ke arah yang negatif. Melalui pengembanganindividu diharapkan secara keseluruhan masyarakat akan mengalami "self empowering" untuk lebih kreatif dan inovatif.Realita yang ada, banyak lulusan pendidikan yang tidak mampu mengisilowongan pekerjaan karena ketidak cocokan antara kemampuan yang dimiliki dengankemampuan yang dibutuhkan dunia kerja Nilai kreatif pun muncul dalam pengembangan pola dasar pembuatan dompet punch zaman now yang mengadopsi dari beberapa reverensi sehingga pola dari dompet ini kekikinian dan mempunyai pola yang menarik. Beberapa pola yang sudah didesain akan dibentuk dalam banner untuk dijadikan dompet. Dari proses penjahitan sampai finishing membutuhkan kedisiplinan dan kerja keras untuk menghasilkan dompet yang sesuai dengan pola.

\section{DAFTAR RUJUKAN}

Asriti. 2011. Grand Design Pendidikan Karakter Berbasis Sekolah, Jurnal Visi Ilmu Pendidikan Vol. 6 No. 3.

Darmiyanti, Zuhdi, Zuhdan Kun Prasetya dan Muhsinatun Siasah Masruri. 2010. Pengembangan Karakter Terintegrasi dalam Pembelajaran Bidang Studi di Sekolah Dasae. Jurnal Cakrawala Pendidikan, Mei 2010, Tahun XXIX.

Davidson, M.L Lickona, T \& Khmelkow V. T 1991. A. 12-Point Comprehensive Approach to Character Education. http://www2.cortland.edu/centers/ character/12-pt-comprehensiveapproach.dot. Diakses pada tanggal 15 April 2018.

Endang, Mulyani, dkk. 2010. Pengembangan Pendidikan Kewirausahaan. Jakarta: Pusat Kurikulum, Badan Penelitian dan Pengembangan, Kementrian Pendidikan Nasional.

Muchlas, Samani \& Hariyanto. 2011. Konsep dan Model Pendidikan Karakter. Bandung: Rosdakarya.

Nuh, Muhammad. 2010. Desain Induk Pendidikan Karakter Pendidikan Nasional. Jakarta: Kementrian Pendidikan Nasional. 
Zulnuraini. 2012. Pendidikan Karakter:

Konsep, Implementasi, dan Pengembangannya di Sekolah Dasar di Kota Palu, Jurnal Dikdas, No. 1, Volume 1, September. 